\title{
PENGEMBANGAN LKPD BERBASIS CERITA BERGAMBAR DIGITAL PADA SISWA KELAS IV SD
}

\author{
Delora Jantung Amelia', Abdurrohman Muzakki \\ delorajantung@umm.ac.id¹, muzakki@umm.ac.id ${ }^{2}$ \\ PGSD, FKIP, Universitas Muhammadiyah Malang ${ }^{1}$ \\ PGSD, FKIP, Universitas Muhammadiyah Malang ${ }^{2}$
}

\begin{abstract}
Abstrak: Berdasarkan analisis kebutuhan yang peneliti laksanakan di SDN Gadingkulon II, peneliti memperoleh informasi bahwa siswa mengalami kesulitan terhadap pemahaman materi selama masa pandemi, siswa juga kurang antusias melaksanakan pembelajaran secara daring, siswa terlambat mengumpulkan dan mengerjakan tugas. Hal tersebut dikarenakan pemberian materi yang diberikan berupa dokumen dalam bentuk bentuk pdf, doc serta Power Point. Soal yang diberikan melalui platform googleform. Degan adanya problematika tersebut membuat kegiatan pembelajaran selama masa pandemic tidak dapat berjalan dengan baik. Oleh karenanya problematika yang ada di lapangan harus segera diatasi. Dari probelmatika diatas dapat diatasi dengan mengembangkan LPDD berbasis cerita bergambar digital. Tujuan dari penelitian ini yaitu mengembangkan bahan ajar LKPD berbasis cerita bergambar yang dapat digunakan sebagai salah satu alternatif bahan ajar yang digunakan dimasa pandemic covid 19 yang layak, praktis dan efektif dan sesuai dengan karakteristik peserta didik. Penelitian ini menggunakan model pengembangan ADDIE yang terdiri dari lima langkah Analyze (analisis), Design (desain), Develop (pengembangan), Implementation (implementasi), dan Evaluation (evaluasi). Subjek penelitian ini adalah siswa kelas IV. Teknik pengumpulan data pada penelitian ini yakni observasi, wawancara, angket dan dokumnetasi. Hasil akhir dari peneltian menunjukkan bahwa hasil Validasi sudah bisa dikatakan layak dimana hasil validasi dari ahli materi mendapatkan tingkat kevalidan $85,5 \%$ dari hasil tersebut sudah masuk ke dalam jenis valid ataupun layak.sedangkan validasi dari ahli bahan ajar memperoleh tingkat kevalidan 94,2\% yang mana dari hasil tersebut pula bisa dikatakan valid ataupun layak untuk diuji cobakan.
\end{abstract}

Kata kunci: bahan ajar, cerita bergambar.

\section{DEVELOPMENT OF LKPD BASED ON DIGITAL PICTURED STORIES IN 4TH GRADE ELEMENTARY SCHOOL STUDENTS}

Abstract: Abstract: Based on the needs analysis carried out by the researchers at SDN Gadingkulon II, researchers obtained information that students had difficulty understanding material during the pandemic, students were also less enthusiastic about carrying out online learning, students were late in collecting and doing assignments. This is because the material provided is in the form of documents in the form of pdf, doc 
Delora, Abdurrohman. Pengembangan LKPD Berbasis Cerita...

and Power Point. Questions given through the googleform platform. With these problems, learning activities during the pandemic cannot run well. Therefore, the problems that exist in the field must be addressed immediately. From the problems above, it can be overcome by developing LPDD based on digital picture stories. The purpose of this research is to develop LKPD teaching materials based on picture stories that can be used as an alternative to teaching materials used during the COVID-19 pandemic that are feasible, practical and effective and in accordance with the characteristics of students. This study uses the ADDIE development model which consists of five steps: Analyze (analyze), Design (design), Develop (development), Implementation (implementation), and Evaluation (evaluation). The subjects of this study were 4th grade students. The data collection techniques in this study were observation, interviews, questionnaires and documentation. The final result of the research shows that the validation results can be said to be feasible where the validation results from material experts get a validity level of $85.5 \%$ of these results have entered the valid or feasible type. which of these results can also be said to be valid or feasible to be tested.

Keywords: teaching materials, picture stories.

\section{PENDAHULUAN}

Sejak masa pandemi yang dialamai oleh berbagi bangsa baik di Negara Indonesia maupun di negara lainnya mengakibatkan dampak yang sangat besar. Tidak terkecuali pada sector Pendidikan mengalami dampak yang sangat besar juga. Pembelajaran yang biasanya dilakukan dengan tatap muka berubah menjadi secara daring. Pada sector Pendidikan yang mana menerapkan kebijakan learning from home atau belajar dari rumah (BDR). Belajar dari rumah dilaksanakan dengan sisrem Pembelajaran Jarak Jauh (PJJ) yang tertuang pada Undang-Undang NO 20. Tahun 2003 pasal 1 ayat 15 yang berisikan bahwa PJJ adalah pendidikan yang peserta didiknya terpisah dari pendidik dan pembelajarannya menggunakan berbagai sumber belajar melalui teknologi komunikasi, informasi dan media lain.

Pada pelaksanaan pembelajaran yang dilaksanakan secara daring pada umumnya banyak menimbulkan problematika diantaranya permasalahan yang terjadi bukan hanya pada ketersediaan fasilitas pembelajaran akan tetapi juga ketiadaan kuota (pulsa) yang membutuhkan biaya cukup tinggi, untuk memperlancar kebutuhan pembelajaran daring, terutama orangtua peserta didik dari kalangan ekonomi menengah ke bawah tidak memiliki anggaran dalam menyediakan jaringan internet. Meskipun pemerintah sudah memberikan kuota gratis untuk kegiatan belajar. peserta didik juga menghadapi kesulitan akses jaringan internet dan penggunaan HP maupun laptop karena tidak 
Delora, Abdurrohman. Pengembangan LKPD Berbasis Cerita...

memiliki sendiri. Hal ini juga menjadi permasalahan yang banyak terjadi pada peserta didik yang mengikuti pembelajaran daring, sehingga pelaksanaannya kurang efektif (Kemdikbud, 2020).

Problematika tersebut juga dialami di SDN Gadingkulon II selama masa pandemi covid 19 diketahui bahwa proses kegiatan belajar mengajar yang selama ini dilakukan secara tatap muka berganti menjadi pembelajaran secara daring mengalami problematika yang sangat komplit. Siswa sulit dikondisikan selama pembelajaran daring berbeda dengan pembelajaran yang dilakukan secara tatap muka. Siswa sering merasa bosan dengan materi yang diberikan karena materi yang diberikan berupa file-file saja serta tugas diberikan melalui google form. Hal tersebut memilik dampak yang luar biasa terhadap hasil belajar siswa kelas IV oleh karenanya salah satu teknologi informasi dalam proses pembelajaran yang sedang berkembang pesat penggunaannya adalah android. Dengan menggunakan HP saja peserta didik dapat belajar. Pembelajaran yang dilakukan melalui android dapat mengatasi kesulitan belajar yang dikarenakan adanya hambatan jarak, letak geografis, dan waktu. Keuntungan penggunaan e-learning menurut Alfianika, 2019, Putri. L.H 2014 yaitu e-learning memperkuat manipulasi informasi, elearning berfungsi sebagai fasilitator komunikasi, dan e-learning berfungsi sebagai media pembelajaran digital (Thowfeek \& Salam, 2014).

Perlu ada bahan ajar yang sesuai dengan kebutuhan di masa pandemik Cerita bergambar yang sesuai dengan karakteristik siswa di masa transisi antara kelas awal dengan kelas tinggi yaitu kelas IV yang mulai menyukai cerita bergambar dapat menjadi salah satu alternatif yang dapat mengatasi problematika tersebut. Cerita bergambar dalam bentuk komik sebagai suatu bahan ajar di kelas yang mana memiliki bentuk yang sangat beragam Menurut Prastowo, 2011 LKPD itu sendiri merupakan bahan ajar cetak yang berisi ringkasan materi pembelajaran dan dilengkapi oleh petunjuk dalam menyelesaikan tugas-tugas yang harus dikerjakan oleh peserta didik, berdasarkan pada kompetensi dasar yang harus dicapai. LKPD bisa berujud lembaran-lembaran kertas atau bisa juga dalam bentuk buku. Selain itu, LKPD dapat memberikan kesempatan siswa dalam mengembangkan proses komunikasi melalui lisan atau Gerakan untuk menujukkan sesuatu kepada sendirinya yang dapat membantu siswa untuk memahami materi selama pembelajaran (Ayva, 2012). Ulas, Sevim, dan Tan (2011), memaparkan bahwa LKPD merupakan suatu lembar kerja yang sudah diupayakn untuk siswa agar tidak bosan saat 
Delora, Abdurrohman. Pengembangan LKPD Berbasis Cerita...

kegiatan pembelajaran yang dapat meningkatkan keberhasilan siswa dalam mencapai tujuan pembelajaran. Tujuan dari penelitian ini menumbuh kembangkan minat belajar, menumbuhkan imajinasi siswa, menciptakan bahan ajar yang menarik. Tujuan tersebut sejalan dengan penelitian yang dilakukan oleh miqro, dkk, 2021 yang menyatahkan bahwa LKPD elektronik sangat efektif sebagai media pembelajaran di masa pandemi covid 19.

\section{METODE}

Penelitian ini merupakan penelitian pengembangan Reserch and Development (R\&D). metode penelitian dan pengembangan yang digunakan untuk menghasilkan dan menguji keefektifan produk tertentu Sugiyono, 2013 penelitian pengembangan merupakan penelitian yang akan menghasilkan sebuah produk dengan melalui pengujian keefektifan produk. Dalam penelitian ini menggunakan model pengembangan ADDIE. Berdasarkan Molenda, 2003 model penelitian yang dilakukan ADDIE, peneliti melakukan beberapa langkah-langkah yang dapat di implementasikan dalam pengembangan media ini dengan lima tahapan diantaranya: (1) Analisis (Analyze), (2)Perencanaan (Design), (3) Pengembangan (De5elopment), (4) Implementasi (Implementation), dan (5) Evaluasi(Evaluation). Adapun skema dari langkah-langkah diatas adalah sebagai berikut :

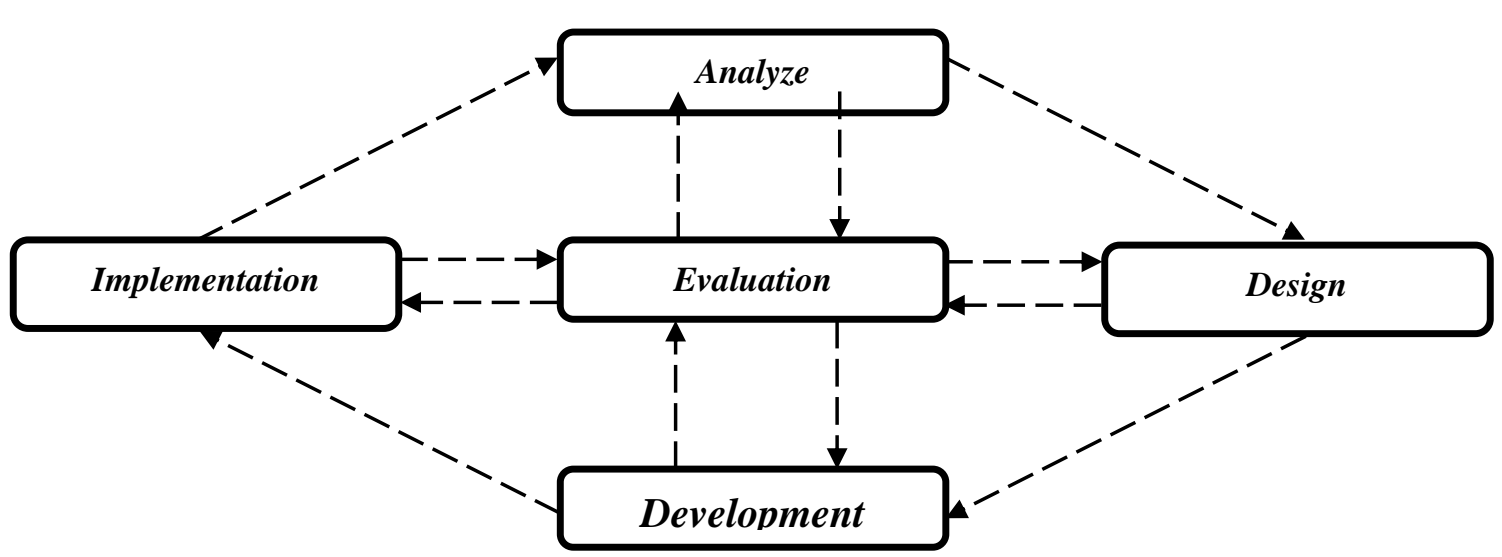

Gambar Model ADDIE Molenda, 2003

1. Analisis (Analysis)

Tahap analisis merupakan tahap awal yang dilakukan oleh peneliti untuk menganalisis permasalahan yang terjadi sehingga menimbulkan perlu atau tidaknya 
Delora, Abdurrohman. Pengembangan LKPD Berbasis Cerita... pengembangan LKPD berbasis cerita bergambar digital serta menganalisis kelayakan dan syarat pengembangan. Peneliti melakukan analisis dengan mengumpulkan data dan menganalisis masalah yang terjadi di SDN Gadingkulon II. Peneliti mendapatkan informasi dengan melakukan observsi beserta wawancara kepada siswa kelas IV SD, beserta walikelas. Tahap ini peneliti sudah melakukan pengindentifikasian standart kompetensi dasar pada materi kelas IV semester II.

2. Perencanaan (Design)

Perencanaan merupakan tahap kedua dari model ADDIE, yang mana pada tahap ini dimulainya tahap perencanaan pembuatan LKPD berbasis cerita digital Bedasarkan hasil observasi dan wawancara kepada wali kelas dan siswa kelas IV SD Gadingkulon II, peneliti menemukan permasalahan dalam bidang alat penunjang pembelajaran yaitu LKPD. Peneliti telah merancang produk LKPD yang dapat mengatasi permasalahan tersebut yaitu LKPD berbasis cerita bergambar digital yang dapat membantu guru menyampaikan materi pembelajaran serta memperlancarkan proses belajar mengajar dalam kelas.

3. Pengembangan (Development)

Tahap pengembangan ini memiliki beberapa langkah-langkah yang harus dilakukan, yaitu: perancangan LKPD berbasis cerita bergambar digital. Pada tahap pertama peniliti harus merancang sedetail mungkin agar tidak terjadi kesalah pahaman saat menyampaikan materi. Pengembangan LKPD berbasis cerita bergambar disesuaikan dengan karakteristik siswa SDN Gadingkulon II.

4. Implementasi (implementation)

Setelah melalui tahap penyempurnaan produk maka peneliti harus menguji kembali produk yang sudah dikembagkan, hal ini dilakukan untuk mengetahui tingkat keberhasilan produk dan kelayakan produk. Untuk proses pengujian ulang akan dilakukan peneliti secara langsung di lapangan yaitu di kelas IV SDN Gadingkulon II Uji coba dilakukan untuk menentukan keberhasilan produk dalam mencapai tujuan yang diharapkan.

5. Evaluasi (Evaluation)

Setelah melalui tahap implementasi atau proses uji coba LKPD berbasis cerita bergambar digital yang dilakukan kepada siswa kelas IV SDN Gadingkulon II, peneliti sudah mengetahui dan dapat mengukur produk yang dikembangkan berhasil 


\section{Delora, Abdurrohman. Pengembangan LKPD Berbasis Cerita...}

atau tidak. Pada tahap ini peneliti mampu memperbaiki atau melakukan revisi akhir terhadap produk yang di kembangkan bedasarkan masukan yang di dapat dari angket respon.

\section{Teknik pengumpulan Data}

Teknik yang sudah dilakukan peneliti dalam mengumpulkan data berdasarkan fakta yang sedang terjadi dilapangan. Berikut adalah langkah-langkah yang dilakukan peneliti dalam pengumpulan data.

1. Wawancara

Teknik wawancara yang dilakukan guna untuk mengumpulkan data tentang pentingnya dilakukan pengembangan LKPD berbasis cerita bergambar pada siswa kelas IV dengan menggunakan daftar pertanyaan yang berisi tentang pembelajaran di kelas IV SD. Peneliti juga melakukan wawancara dengan kepala sekolah beserta wali kelas IV.

2. Observasi

Teknik observasi yang dilakukan oleh peneliti yakni dengan mengamati faktor penghambat, dan faktor pendukung pada saat pelaksaan uji coba LKPD berbasis cerita bergambar pada siswa kelas IV.

3. Angket

Selain melakukan wawancara dan observasi, peneliti juga menggunakan teknik quisioner atau biasa di sebut dengan angket. Peneliti menggunakan angket ini bertujuan agar peneliti bisa mengetahui respon siswa terhadap LKPD berbasis cerita bergambar pada siswa kelas IV.

4. Dokumentasi

Peneliti juga mengumpulkan data melalui dokumentasi. Dokumentasi yang digunakan pada penelitian pengembangan ini adalah foto pada saat uji coba media, dan video pada saat proses penggunaan media, serta keefektifan siswa setelah

Penelitian dilakukan SDN Gadingkulon II. Penelitian dilakukan dengan teknik pengumpulan data berupa angket (angket validasi bahan ajar LKPD dan angket validasi materi, serta angket respon peserta didik), observasi, wawancara, dan juga dokumentasi. Instrumen penelitian berupa instrumen angket, instrumen observasi, serta instrumen 
Delora, Abdurrohman. Pengembangan LKPD Berbasis Cerita...

wawancara. Instrumen angket terdiri dari angket validasi materi, angket validasi bahan ajar LKPD, dan angket respon peserta didik. Berikut kisi-kisi angket.

Tabel 1. Kisi-Kisi Angket Validasi Ahli Materi

\begin{tabular}{|c|c|c|c|}
\hline No & Aspek & Indikator & Butir Pertanyaan \\
\hline 1 & $\begin{array}{c}\text { Penyajian } \\
\text { Materi }\end{array}$ & $\begin{array}{l}\text { a. Kesesuaian materi dengan } \\
\text { Kompetensi Inti, Kompetensi Dasar } \\
\text { b. Terdapat ringkasan materi yang } \\
\text { sesuai dengan indikator } \\
\text { pembelajaran } \\
\text { c. Materi disajikan sederhana dan jelas } \\
\text { d. Materi yang disajikan sesuai dengan } \\
\text { indicator dan tujuan }\end{array}$ & $\begin{array}{c}3 \\
4,5 \\
6\end{array}$ \\
\hline 2 & $\begin{array}{c}\text { Penyajian } \\
\text { Bahasa }\end{array}$ & $\begin{array}{l}\text { a. Bahasa yang digunakan sesuai } \\
\text { dengan EYD } \\
\text { b. Bahasa yang digunakan jelas dan } \\
\text { tidak membuat peserta didik } \\
\text { bingung } \\
\text { c. Bahasa yang digunakan bersifat } \\
\text { komunikatif }\end{array}$ & $\begin{array}{c}7 \\
8,9\end{array}$ \\
\hline
\end{tabular}

(Sumber: Olahan Peneliti)

Tabel 2. Kisi-Kisi Angket Validasi Ahli Bahan Ajar LKPD

\begin{tabular}{|c|c|c|c|}
\hline No & Aspek & Indikator & Butir Pertanyaan \\
\hline 1 & $\begin{array}{l}\text { Komponen } \\
\text { LKPD }\end{array}$ & $\begin{array}{l}\text { a. Terdapat kompetensi inti, pemetaan } \\
\text { kompetensi dasar dan indikator, tujuan } \\
\text { pembelajaran, petunjuk belajar, serta } \\
\text { kegiatan-kegiatan peserta didik }\end{array}$ & $1,2,3,4,5$ \\
\hline 2 & Desain cover & $\begin{array}{l}\text { a. Desain cover menarik } \\
\text { b. Desain cover sesuai dengan materi } \\
\text { pembelajaran }\end{array}$ & $\begin{array}{l}6 \\
7\end{array}$ \\
\hline 3 & Tampilan isi & $\begin{array}{l}\text { a. Background yang digunakan tidak } \\
\text { mengganggu isi LKPD } \\
\text { b. Terdapat gambar-gambar yang } \\
\text { menarik } \\
\text { c. Gambar dicetak dengan tinta berwarna } \\
\text { d. Teks dapat dibaca dengan jelas } \\
\text { e. Kualitas cetakan }\end{array}$ & $\begin{array}{l}8 \\
9 \\
10 \\
11 \\
12\end{array}$ \\
\hline 4 & $\begin{array}{c}\text { Kegiatan } \\
\text { peserta didik }\end{array}$ & $\begin{array}{l}\text { a. Kegiatan peserta didik berdasarkan } \\
\text { kehidupan sehari-hari }\end{array}$ & 13 \\
\hline 5 & $\begin{array}{l}\text { Kesesuaian } \\
\text { bahasa }\end{array}$ & $\begin{array}{l}\text { a. Bahasa yang digunakan sesuai dengan } \\
\text { EYD } \\
\text { b. Bahasa yang digunakan mudah } \\
\text { dipahami }\end{array}$ & 14 \\
\hline
\end{tabular}

(Sumber: Olahan Peneliti)

Tabel 3. Kisi-Kisi Angket Respon Peserta Didik

\begin{tabular}{|c|l|l|c|}
\hline No & Aspek & \multicolumn{1}{|c|}{ Indikator } & Butir Pertanyaan \\
\hline 1 & Materi & a. & $\begin{array}{l}\text { Materi yang disajikan mudah } \\
\text { dipahami }\end{array}$ \\
\hline 2 & LKPD & $\begin{array}{l}\text { Respon peserta didik terhadap } \\
\text { desain cover LKPD } \\
\text { Respon peserta didik terhadap } \\
\text { tampilan isi LKPD }\end{array}$ & 2,3 \\
\hline
\end{tabular}


Delora, Abdurrohman. Pengembangan LKPD Berbasis Cerita...

\begin{tabular}{|c|c|c|c|}
\hline \hline & c. $\begin{array}{l}\text { Respon peserta didik terhadap } \\
\text { tulisan pada LKPD } \\
\text { d. } \begin{array}{l}\text { Respon peserta didik terhadap } \\
\text { gambar pada LKPD }\end{array}\end{array}$ & 6,8 \\
\hline 3 & Bahasa & a. $\begin{array}{l}\text { Bahasa yang digunakan mudah } \\
\text { dipahami } \\
\text { bahasa sesuai dengan EYD }\end{array}$ & 9 \\
\hline
\end{tabular}

Angket validasi terhadap validator ahli bahan ajar dan validator ahli materi serta angket respon dibuat dengan skala likert dengan menggunakan cara checklist dengan skor maksimal yaitu 4 dan skor minimal yaitu 1. Skor yang diperoleh akan dianalisis dengan menggunakan rumus:

$$
\text { Presentase }=\frac{\text { jumlah nilai yang diperoleh }}{\text { jumlah nilai maksimal }} \times 100 \%
$$

Kriteria validasi dalam penelitian pengembangan bahan ajar LKPD ini sebagai berikut.

\section{Tabel 4. Kriteria Validasi}

\begin{tabular}{|c|c|c|}
\hline Tingkat Pencapaian & Kualitas & Keterangan \\
\hline $81-100 \%$ & Sangat Baik & Sangat menarik, sangat baik, tidak revisi \\
\hline $61-80 \%$ & Baik & Menarik, baik, sedikit revisi \\
\hline $41-60 \%$ & Cukup & Kurang menarik, kurang baik, sedikit revisi \\
\hline $21-40 \%$ & Kurang & Tidak menarik, tidak baik, revisi \\
\hline$<21 \%$ & Sangat Kurang & Sangat tidak menarik, sangat tidak baik, revisi \\
\hline
\end{tabular}

\section{HASIL}

Penelitian pengembangan ini menggunakan model ADDIE dengan tahap-tahap yang terdiri dari Analyze, Design, Development, Implementation, dan Evaluation. Berikut penjelasan dari tahap-tahap model penelitian pengembangan ADDIE, yaitu:

\section{Tahap Analyze}

Hasil dari observasi awal di kelas IV SDN Gadingkulon II serta wawancara dengan guru dapat diketahui bahwa dalam kegiatan belajar di kelas IV sudah menggunakan beberapa bahan ajar, yaitu buku paket dan juga LKPD. Akan tetapi semenjak bencana covid yang melanda bangsa Indonesia pembelajaran yang awalnya dilakukan secara tatap muka sekarang berubah menjadi pembelajaran secara daring. Perubahan tersebut mengakibatkan beberapa problematika yang harus segera diatasi diantaranya peserta didik engan belajar di rumah, peserta didik sulit mengumpulkan tugas secara tepat waktu. Peserta didik dapat dikatakan tidak terlalu aktif untuk perihal kehadiran, kaktifan dalam mengerjakan tugas dari guru. Keaktifan peserta didik yang masih kurang disebabkan oleh suasana belajar yang 
Delora, Abdurrohman. Pengembangan LKPD Berbasis Cerita... berbeda Bahan ajar LKPD yang digunakan saat ini masih berupa file yang membuat siswa tidak teralalu aktif dalam megerjakan.

\section{Tahap Design}

Pada langkah perancangan pengembangan LKPD didapatkan hasil sebagai berikut.

a. Peneliti mengumpulkan beberapa referensi dan unsur-unsur pendukung dalam penyusunan dan penulisan LKPD, antara lain: materi yang diakan diajarkan, gambar-gambar yang akan digunakan, serta beberapa font selain Arial yang akan digunakan pada LKPD.

b. Mempersiapkan beberapa aplikasi yang digunakan dalam penyusunan LKPD berbasis cerita bergambar digital.

c. Merumuskan indikator dan tujuan pembelajaran yang akan dicapai dalam pembelajaran.

d. Menyusun isi LKPD, dari materi sampai dengan soal-soal atau kegiatan yang akan dilakukan oleh peserta didik.

\section{Tahap Development}

Tahap selanjutnya yaitu tahap development atau tahap pengembangan. Pada tahap ini, pengembangan LKPD tematik berbasis cerita bergambar digital. Tahap pengembangan dilakukan dengan 2 tahap, yaitu tahap pengembangan LKPD dan tahap validasi oleh para ahli (ahli bahan ajar LKPD dan ahli materi).

a. Tahap Validasi LKPD berbasis cerita bergambar digital

Tahap selanjutnya yaitu tahap validasi LKPD, di mana terbagi menjadi 2 bagian, tahap validasi bahan ajar LKPD serta tahap validasi materi. Validasi dilakukan guna mengetahui kevalidan LKPD yang dikembangkan dan yang akan digunakan. Validasi dilakukan dengan mengisi angket validasi dengan memberi tanda checklist $(\sqrt{ })$.

1) Validasi Ahli Bahan Ajar LKPD

Penilaian terdiri dari beberapa aspek, antara lain komponen LKPD, desain cover/sampul, tampilan isi, kegiatan peserta didik, serta kesesuaian bahasa.

Tabel 5. Validasi Bahan Ajar LKPD

\begin{tabular}{|l|c|c|c|}
\hline No. & Aspek & Indikator & Skor \\
\hline
\end{tabular}


Delora, Abdurrohman. Pengembangan LKPD Berbasis Cerita...

\begin{tabular}{|c|c|c|c|c|c|c|}
\hline & & & 4 & 3 & 2 & 1 \\
\hline \multirow{5}{*}{1} & \multirow{5}{*}{$\begin{array}{l}\text { Komponen } \\
\text { LKPD }\end{array}$} & $\begin{array}{l}\text { Terdapat Kompetensi Inti pada } \\
\text { Lembar Kegiatan Peserta Didik } \\
\text { (LKPD) }\end{array}$ & $\sqrt{ }$ & & & \\
\hline & & $\begin{array}{l}\text { Terdapat Kompetensi Dasar dan } \\
\text { Indikator dalam LKPD }\end{array}$ & $\sqrt{ }$ & & & \\
\hline & & $\begin{array}{l}\text { Adanya tujuan pembelajaran dalam } \\
\text { LKPD }\end{array}$ & $\sqrt{ }$ & & & \\
\hline & & $\begin{array}{l}\text { Adanya petunjuk belajar yang } \\
\text { memudahkan penggunaan LKPD }\end{array}$ & $\sqrt{ }$ & & & \\
\hline & & $\begin{array}{l}\text { Terdapat kegiatan-kegiatan peserta } \\
\text { didik yang sesuai dengan materi }\end{array}$ & $\sqrt{ }$ & & & \\
\hline \multirow{2}{*}{2} & \multirow{2}{*}{ Desain cover } & $\begin{array}{l}\text { Desain cover menarik baik gambar } \\
\text { maupun warna yang digunakan }\end{array}$ & & $\sqrt{ }$ & & \\
\hline & & $\begin{array}{l}\text { Desain cover sesuai dengan materi } \\
\text { pembelajaran }\end{array}$ & & $\sqrt{ }$ & & \\
\hline \multirow{5}{*}{3} & \multirow{5}{*}{ Tampilan isi } & $\begin{array}{l}\text { Background yang digunakan tidak } \\
\text { mengganggu isi dari LKPD }\end{array}$ & $\sqrt{ }$ & & & \\
\hline & & $\begin{array}{l}\text { Gambar-gambar yang terdapat pada } \\
\text { LKPD menarik }\end{array}$ & & $\sqrt{ }$ & & \\
\hline & & $\begin{array}{l}\text { Gambar-gambar dicetak } \\
\text { menggunakan tinta berwarna }\end{array}$ & & $\sqrt{ }$ & & \\
\hline & & $\begin{array}{l}\text { Teks yang terdapat dalam LKPD } \\
\text { dapat dibaca dengan jelas }\end{array}$ & & $\sqrt{ }$ & & \\
\hline & & Kualitas cetakan LKPD & & $\sqrt{ }$ & & \\
\hline 4 & $\begin{array}{c}\text { Kegiatan } \\
\text { peserta didik }\end{array}$ & $\begin{array}{l}\text { Kegiatan peserta didik berdasarkan } \\
\text { kehidupan sehari-hari (contextual } \\
\text { teaching and learning) }\end{array}$ & & $\sqrt{ }$ & & \\
\hline \multirow[t]{2}{*}{5} & \multirow{2}{*}{$\begin{array}{l}\text { Kesesuaian } \\
\text { bahasa }\end{array}$} & $\begin{array}{l}\text { Bahasa yang digunakan sesuai } \\
\text { dengan Ejaan Yang Disempurnakan } \\
\text { (EYD) }\end{array}$ & $\sqrt{ }$ & & & \\
\hline & & $\begin{array}{l}\text { Bahasa yang digunakan mudah } \\
\text { dipahami }\end{array}$ & $\sqrt{ }$ & & & \\
\hline \multicolumn{3}{|r|}{$\begin{array}{l}\text { Jumlah Skor } \\
\text { Skor Maksimal } \\
\text { Presentase }\end{array}$} & \multicolumn{4}{|c|}{$\begin{array}{c}60 \\
85,5 \%\end{array}$} \\
\hline
\end{tabular}

Berdasarkan perhitungan data, diperoleh hasil dengan tingkat pencapaian 85,5\% dan dengan kualitas sangat baik, namun masih ada sedikit revisi.

2) Validasi Ahli Materi Pembelajaran Tematik

Validator ahli materi pembelajaran penilaian terdiri dari aspek penyajian materi dan aspek penyajian bahasa. Berikut penilaian dari validator ahli materi pembelajaran tematik.

Tabel 6. Validasi Materi

\begin{tabular}{|c|c|c|c|c|c|c|}
\hline \multirow{2}{*}{ No. } & \multirow{2}{*}{ Aspek } & \multirow{4}{*}{ Indikator } & \multicolumn{4}{|c|}{ Skor } \\
\cline { 3 - 6 } & & 4 & 3 & 2 & 1 \\
\hline
\end{tabular}


Delora, Abdurrohman. Pengembangan LKPD Berbasis Cerita...

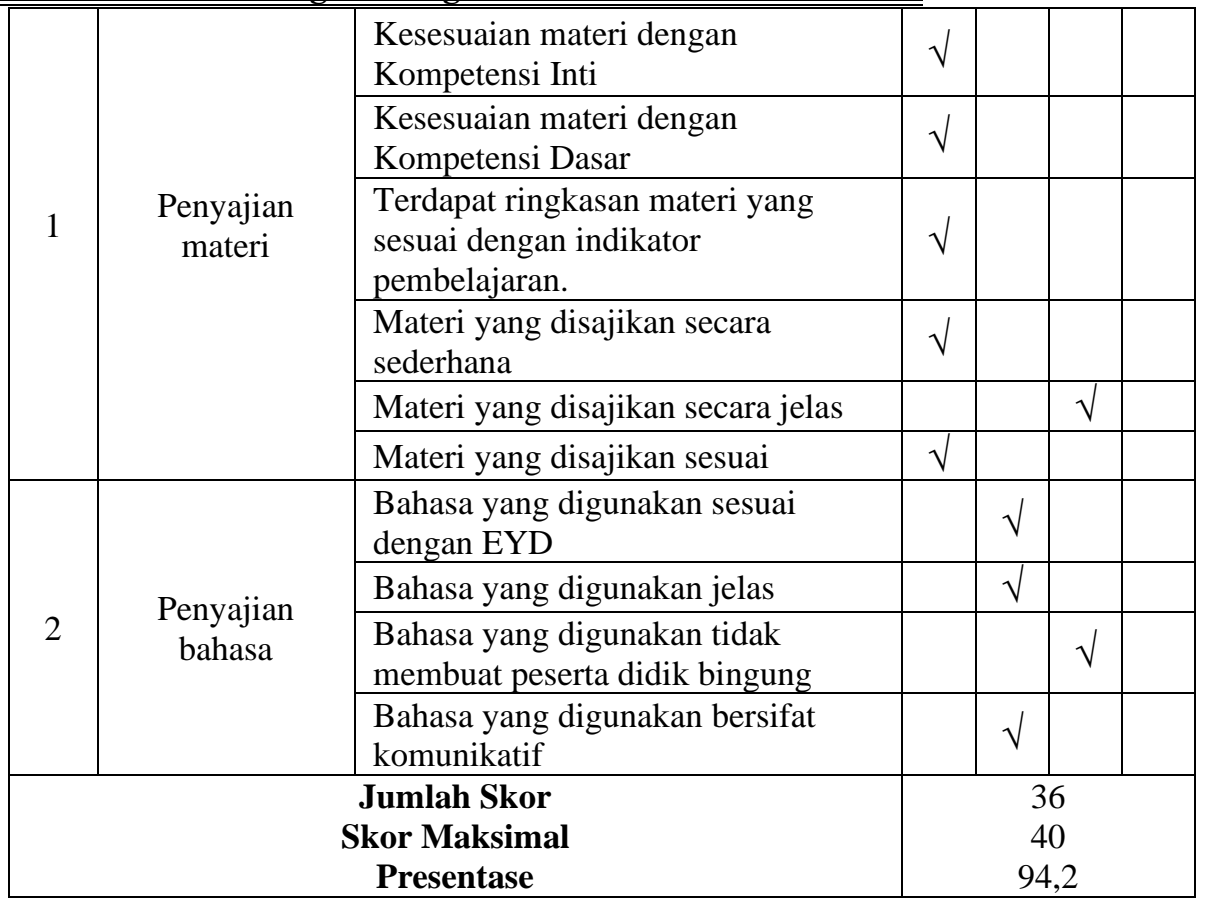

Berikut hasil respon peserta didik terhadap LKPD berbasis cerita bergambar digital.

Tabel 7. Respon Peserta Didik

\begin{tabular}{|c|l|c|c|}
\hline \multirow{2}{*}{ No Indikator } & \multicolumn{2}{c|}{ Respon } \\
\cline { 2 - 4 } & \multicolumn{1}{|c|}{ Ya } & Tidak \\
\hline Aspek Materi & 21 & 0 \\
\hline 1 & Saya dapat memahami dengan mudah materi pada LKPD & 20 & 1 \\
\hline Aspek Bahan Ajar LKPD & 20 & 1 \\
\hline 2 & Saya menyukai cover LKPD & 21 & 0 \\
\hline 3 & Cover LKPD sangat menarik perhatian saya & 4 \\
\hline 4 & Saya menyukai tampilan isi di dalam LKPD & 17 & 0 \\
\hline 5 & $\begin{array}{l}\text { Tampilan background di dalam LKPD tidak membuat saya } \\
\text { bingung dengan teks di dalamnya }\end{array}$ & 21 & 1 \\
\hline 6 & $\begin{array}{l}\text { Saya dapat membaca dengan jelas teks yang terdapat pada } \\
\text { LKPD }\end{array}$ & 20 & 2 \\
\hline 7 & $\begin{array}{l}\text { Saya menyukai gambar-gambar yang ditampilkan dalam } \\
\text { LKPD }\end{array}$ & 19 & \\
\hline 8 & $\begin{array}{l}\text { Warna-warna yang terdapat pada gambar-gambar yang ada } \\
\text { di LKPD sangat menarik perhatian saya }\end{array}$ & 21 & 0 \\
\hline Aspek Bahasa & $\begin{array}{l}\text { Saya dapat memahami dengan mudah bahasa yang } \\
\text { digunakan dalam LKPD }\end{array}$ & 21 & 0 \\
\hline $\begin{array}{l}\text { Saya dapat membaca dengan lancer teks dalam LKPD } \\
\text { karena telah sesuai dengan EYD }\end{array}$ & 21 \\
\hline
\end{tabular}

(Sumber: Olahan Peneliti) 
Delora, Abdurrohman. Pengembangan LKPD Berbasis Cerita...

Berdasarkan tabel hasil respon peserta didik, dapat diketahui bahwa memperoleh persentase 95,7\%. Hal tersebut membuktikan bahwa LKPD berbasis cerita bergambar digital yang dikembangkan oleh peneliti sangat menarik, layak dan valid.

\section{Tahap Evaluation}

Tahap evaluasi dilakukan dari tahap analisis pada model ADDIE. Pada tahap analisis, peneliti mendapatkan beberapa saran untuk mengambil topik yang akan dikembangkan. Keadaan sekolah yang dijadikan sasaran penelitian saat ini Tahap pengembangan juga melewati evaluasi, demi menyempurnakan tampilan pada LKPD, baik dari segi warna, bentuk, gambar, serta font yang digunakan. Pada tahap pengembangan banyak sekali perbaikan-perbaikan yang mana hal tersebut ditambahkan maupun diubah, seperti pada penyusunan kompetensi dasar, indikator, serta tujuan pembelajaran. Komponen-komponen tersebut mengalami beberapa kali perubahan agar memberikan kesan baru dan berbeda, apabila LKPD digunakan oleh peserta didik.

Evaluasi yang terakhir yaitu evaluasi pada tahap implementasi atau penerapan LKPD terhadap peserta didik. Berdasarkan hasil angket respon peserta didik dan juga hasil wawancara kepada guru kelas dapat digunakan sebagai evaluasi atau perbaikan.

\section{a. Evaluasi Sumatif}

Pada tahap evaluasi sumatif LKPD berbasis berbasis media gambar digital yang dikembangkan oleh peneliti untuk peserta didik kelas IV Sekolah Dasar, sudah termasuk kriteria menarik, valid, dan layak. Dengan adanya evaluasi, akan semakin menyempurnakan dan menutup kekurangan-kekurangan yang sebelumnya ada pada LKPD yang telah dikembangkan.

\section{PEMBAHASAN}

Berdasarkan hasil analisis kebutuhan yang ada pada tahap analyze, peneliti memperoleh informasi dari kegiatan observasi dan juga wawancara, yaitu selama pandemi sekolah telah melakukan pembelajaran secara daring yang mana perangkat pembelajaran diberikan melalui whatsaapgroup akan tetapi sekolah mengalami problematika yaitu siswa kurang antusias belajar tanpa pendampingan guru, siswa sulit 
Delora, Abdurrohman. Pengembangan LKPD Berbasis Cerita...

untuk mengerjakan tugas, siswa sering terlambat mengumpulkan tugas sehingga kegiatan pembelajaran tidak berlangsung dengan baik. Oleh karenanya perlu perangkat pembelajaran yang dapat mengatasi problematika tersebut. LKPD berbasis cerita bergambar digital dipilih karena LKPD sendiri diungkapkan oleh Prastowo, 2015 sebagai bahan ajar cetak yang berupa lembar-lembar kertas yang berisi materi, ringkasan, dan petunjuk pelaksanaan kegiatan yang harus dikerjakan oleh peserta didik yang mana hal tersebut mengacu pada kompetensi dasar yang harus dicapai. Sehingga, diperlukan LKPD yang menarik agar peserta didik mampu melaksanakan kegiatankegiatan dengan maksimal. LKPD berbasis komik juga dapat meningkatkan hasil belajar peserta didik hal tersebut sejalan dengan penelitian Utomo, 2018 dengan adanya LKPD dapat meningkatkan literasi dan nilai peseta didik.

Tahap development atau pengembangan, yang mana dalam tahap pengembangan ini, dilakukan untuk mengembangkan LKPD yang telah dirancang pada tahap sebelumnya. Dalam tahap pengembangan ini terdapat 2 tahap, yaitu pengembangan LKPD dan juga tahap validasi oleh para ahli, baik ahli bahan ajar LKPD maupun ahli materi. Tahap pengembangan LKPD dilakukan mulai dari penyusunan sampul depan dan belakang LKPD, kemudian dilanjutkan dengan pusat perbukuan, kata pengantar, petunjuk belajar, daftar isi, kompetensi inti, daftar pustaka, Dalam pembelajaran 1 sampai dengan pembelajaran 3, terdapat komponen-komponen seperti kompetensi dasar, indikator, tujuan pembelajaran, serta kegiatan-kegiatan yang akan dilakukan oleh peserta didik. Setelah itu LKPD yang telah dikembangkan melewati tahap validasi kepada validator ahli, yang pertama yaitu validasi kepada validator ahli materi LKPD dengan persentase $85,5 \%$ dengan kategori sangat baik. Kemudian dilanjutkan dengan validasi kepada validator ahli bahan ajar yang dilakukan sebanyak 2 kali validasi, dengan validasi tahap, persentase 66,5\% dengan kategori revisi kecil, sedangkan dalam validasi tahap kedua mendapatkan persentase 94,2,5\% dengan kategori sangat baik. Berdasarkan hasil yang diperoleh, maka dapat disimpulkan bahwa LKPD berbasis cerita bergambal digital yang dikembangkan oleh peneliti layak digunakan dalam kegiatan belajar mengajar. Tahap selanjutnya yaitu tahap penerapan atau implementasi. Pada tahap ini dilakukan uji coba produk LKPD berbasis cerita bergambar digital pada peserta didik Sekolah Dasar. dengan melalui 2 jalur, yaitu pertama dilaksanakan secara tatap muka dengan tetap melaksanakan protokol kesehatan, yaitu menjaga jarak dan menggunakan 
Delora, Abdurrohman. Pengembangan LKPD Berbasis Cerita...

masker, dan yang kedua yaitu daring menggunakan zoom meeting. Kegiatan penerapan atau uji coba produk ini dilakukan untuk mengetahui keberhasilan dari pengembangan LKPD tersebut, dengan melakukan pengisian angket respon peserta didik terhadap LKPD berbasis cerita bergambar digital dengan kegiatan observasi, serta dengan kegiatan wawancara kepada guru kelas.

Pada tahap akhir yaitu tahap evaluasi dibagi menjadi 2 bagian, yaitu evaluasi formatif yang dilakukan pada setiap tahap pengembangan yang dilakukan oleh peneliti, dimulai dari tahap analisis, tahap perancangan, tahap pengembangan, sampai dengan tahap penerapan. Evaluasi formatif dilakukan guna memperbaiki dan menyempurnakan setiap tahapannya, sehingga dalam mengembangkan LKPD dapat dimaksimalkan dan sesuai dengan kebutuhan. Kemudian evaluasi sumatif, di mana dalam evaluasi sumatif ini dilakukan untuk mengetahui hasil dari pengembangan itu sendiri, dan pada penelitian ini, dapat diambil kesimpulan apakah LKPD berbasis cerita bergambar digital yang dikembangkan oleh peneliti untuk peserta didik kelas IV Sekolah Dasar sudah termasuk dalam kriteria menarik, valid, dan layak. Dengan adanya evaluasi ini, akan semakin menyempurnakan LKPS yang telah dikembangkan, sehingga LKPD tersebut dapat digunakan sebagai inovasi baru dalam pembelajaran, sehingga pembelajaran semakin menarik dan bermakna bagi peserta didik. Selain itu, dapat diketahui bahwa LKPD yang dikembangkan mampu meningkatkan peran aktif peserta didik dalam kegiatan belajar mengajar.

Pengembangan LKPD berbasis cerita bergambar digital menjawab kebutuhankebutuhan yang dibutuhkan Adapun berbedaan LKPD yang sudah diberikan di sekolah dengan LKPD yang dikembangkan oleh peneliti sesuai dengan Prastowo, 2011 sebagai berikut: 1) LKPD yang dikembangkan dapat mengembangkan segala aspek kemampuan peserta didik, 2) LKPD yang dikembangkan dapat digunakan sebagai suatu alternatif untuk menguatkan materi yang diberikan serta 3) LKPD yang dikembangkan dapat meningkatkan aktivitas peserta didik.

Dengan menggunakan LKPD berbasis cerita bergambar ini kegiatan pembelajaran siswa menjadi sangat praktis dan menyenangkan dikarenakan hal tersebut masih baru dilakukan di sekolah sesuai dengan Rani, 2021 menyatahkan bahawa pembelajaran dengan menggunakan LKPD bergambar sangat praktis dan menyenangkan, LKPD berbasis cerita bergambar juga dapat meningkatkan hasil belajar 
Delora, Abdurrohman. Pengembangan LKPD Berbasis Cerita...

dengan adanya gambar-gambar di dalamnya mempermudah peserta didik untuk memahami materi yang ada di dalamnya sejalan dan sesuai dengan penelitian yang dilakukan oleh Nigsih, 2016. Penggunaan bahan ajar LKPD berbasis cerita bergambar berbasis e-lerning memberikan energi postif menjadi lebih baik terkait hasil dari kegiatan pembelajaran hal tersebut sejalan dengan penelitian e-lerning yang suah dilakukan oleh kultawanich, koraneekij\&nasongkhla, 2015, Putri lita hapsari, 2014 serta Dini 2019.

\section{SIMPULAN}

Kesimpulan dari penelitian ini dengan bahan ajar LKPD berbasis cerita bergambar dapat digunakan sebagai salah satu alternatif bahan ajar yang digunakan dimasa pandemic covid 19 yang layak, praktis dan efektif dan sesuai dengan karakteristik peserta didik., LKPD berbasis cerita bergambar dapat mengembangkan segala aspek kemampuan peserta didik. Hasil akhir dari peneltian menunjukkan bahwa hasil Validasi sudah bisa dikatakan layak dimana hasil validasi dari ahli materi mendapatkan tingkat kevalidan $85,5 \%$ dari hasil tersebut sudah masuk ke dalam jenis valid ataupun layak.sedangkan validasi dari ahli bahan ajar memperoleh tingkat kevalidan 94,2\% yang mana dari hasil tersebut pula bisa dikatakan valid ataupun layak untuk diuji cobakan.

\section{DAFTAR RUJUKAN}

Alfianika, S., \& Marni, S. (2019). Pengembangan Lembar Kegiatan Siswa Berbasis Komik pada Materi Menulis Poster dan Slogan. Jurnal Kependidikan, 3 (1), 4353. Retrieved from https://journal.uny.ac.id/index.php/ jk/article/view/13163/pdf Ayva, Ozge. 2012. Developing Students' Ability to Read, Understand and Analyze Scientific Data Through The Use Of Worksheets That Focus On Studying Historical Documents. Procedia Social and Behavioral Sciences. Vol. 46. Juni 2012: $5128-5132$.

Dini Rahma Diani, 2019. Pengembangan Lembar Kerja Peserta Didik Menulis Cerpen Berbasis Aplikasi Android. 1-13 Jurnal Basastra Jurnal Bahasa, sastra dan pengajaran. Volume 7 Nomor 2. 
Delora, Abdurrohman. Pengembangan LKPD Berbasis Cerita...

Eko Prasetyo Utomo, 2018. Pengembangan LKPD Berbasis Komik Untuk Meningkatkan Literasi Ekonomi Peserta Didik. Jurnal Penelitian Pendidikan $\begin{array}{lllll}\text { Vol } & 35 & \text { Nomor } & 1 & \text { Tahun }\end{array}$ https://journal.unnes.ac.id/nju/index.php/JPP/article/view/14015.

Kim, D. H., Jang, H. G., Shin, D. S., Kim, S. J., Yoo, C. Y., dan Chung, M. S. 2012. Science Comic Strips. Journal of Education and Learning. Vol. 1 (2): 65-71

Kultawanich, K., Koraneekij, P., \& NaSongkhla, J. (2015). A Proposed Model of Connectivism Learning Using Cloud-Based Virtual Classroom to Enhance Information Literacy and Information Literacy Self-Efficacy for Undergraduate Students. Procedia-Social and Behavioral Sciences, 191, 87-92. https://doi.org/10.1016/j.sbspro.20 15.04.394.

Nigsih, Endah Rahayu. 2016. Pengembangan Lembar Kerja Siswa Berbasis Cerita Bergambar Melalui Pendekatan Discovery Learning pada Mata Pelajaran Ilmu Pengetahuan Alam Kelas 5 SD Negeri Samban 02. Jurnal Premary School Teacher Education.

Miqro' Fajari Lathifah, dkk, 2021. Efektivitas LKPD Elektronik sebagai Media Pembelajaran Pada Masa Pandemi Covid 19 Untuk Guru YPI Bidayatul Hidayah Ampenen. Jurnal Magister Pendidikan IPA.

Molenda, M. In Search of the ellusive ADDIE model. Performance Improvement, 42 (5), 34-36. Submitted for publication in A. Kovalchick \& K. Dawson, Ed's, Educational Technology: An Encyclopedia. Copyright by ABCClio, Santa Barbara, CA, 2003. Diakses dari laman http://www.indian.edu, pada 10 April 2018 .

Prastowo, Andi. 2011. Panduan Kreatif Membuat Bahan Ajar Inofatif: Menciptakan Metode Pembelajaran yang Menarik Dan Menyenangkan. Yogjakarta: Diva Press

Prastowo, A. (2015). Panduan Kreatif Membuat Bahan Ajar Inovatif. DIVA Press.

Putri, L. H. (2014). Pengaruh Penggunaan Internet dalam Pembelajaran Jarak Jauh (E-Learning) terhadap Efektivitas Pengajaran Bahasa Indonesia Kepada 
Delora, Abdurrohman. Pengembangan LKPD Berbasis Cerita... Penutur Asing. Paper presented at the Asile 2014 Conference, Bali, Indonesia. Retrieved from https://www.eprints.uny.ac.id.

Rani Setiya Wati, Nurlaeli, Miftahul Husni. 2021. Pengembangan Lembar Kerja Berbasis Cerita Bergambar. Journal Of Intergrated Elementary Education. https://journal.walisongo.ac.id/index.php/jieed/article/view/7774/pdf

Rota, G., dan Izqulerdo, J. 2003. Comics as A Tool for Teaching Biotechnology In Primary Schools. Electronic Journal of Biotechnology. Vol. 6(2): 85-89.

Sugiyono. 2017. Metode Penelitian Pendidikan: Pendekatan Kuantitatif, Kualitatif, Dan R\&D. Bandung: Penerbit Alfabeta.

Tatang Supriatna, Matahari, Muhammad Ihan. 2020. Pengembangan Lembar Kerja Peserta Didik Berbasis Komik Digital Pada Materi Sistem Bilangan Mata Pelajaran Sistem Komputer Kelas X. Jurnal Petisi Vol 1 No 22020

Thowfeek \& Salam. (2014). Student's Assesment on the Usability of ELearning Websites. Procedia: Social and Behavioral Sciences, 141, 916-922

Sugiyono. 2017. Metode Penelitian Pendidikan: Pendekatan Kuantitatif, Kualitatif, Dan $R \& D$. Bandung: Penerbit Alfabeta.

Ulas, A. H., Sevim, O., dan Tan, E. 2012. The Effect of Worksheets Based Upon 5E Learning Cycle Model On Student Success in teaching of adjectives as Grammatical Components. Procedia Social and Behavioral Sciences. Vol. 31. 2012: 391-398.

Undang-undang Nomor 20 tahun 2003 tentang Sistem Pendidikan Nasional. 